\title{
Histocompatibility antigens (HLA) in multiple sclerosis in Iran
}

\author{
J . L O T F I, B. N I K B I N, I D E R A K H S H N, Z A G H A I, \\ A N D F. A L A
}

From Dariush Kabir Medical School, University of Teheran, and Iranian National Blood Transfusion Service, Teheran, Iran

SUMMARY Thirty-five patients (19 male and 16 female) with clinically definite multiple sclerosis and 100 healthy control subjects were studied for the A and B locus of the HLA system. A significant increase of HLA A3 and A11 of the A locus and B7 of the B locus was observed in patients with multiple sclerosis compared with controls. An increase of antigen A3 was also observed in eight cases of probable multiple sclerosis. A significant increase of both A3 and B7 was observed in patients with multiple sclerosis.

As multiple sclerosis occurs 12 to 20 times more frequently within the family of a given patient compared to the population at large (Leibewitz and Alter, 1973), genetic predisposition has long been suspected to be a factor in aetiology. Since the histocompatibility system is one of the largest genetic marker systems found in man, the study of an association between HLA and disease has been of great interest. The association between certain HLA determinants and multiple sclerosis has been reported from several parts of the world (Bertrams et al., 1972; Jersild et al., 1973a, b; Bertrams and Kuwert, 1976), showing strong association between HLA A3, B7, and the disease, though these results have not been reproduced in some studies, notably those from Israel and Japan (Brautbar et al., 1976; Saito et al., 1976). In a previous study we have shown that the distribution of some of the HLA antigens in Iran differs from that in other populations, especially European Caucasians (Nikbin et al., 1975). In view of the importance of geographical factors in the aetiology of the disease (Kurtzke, 1977), it seemed interesting to study the association between HLA and multiple sclerosis in Iran where the disease is thought to be rare.

\section{Subjects and methods}

Nineteen male and 16 female patients with clinically definite and eight patients with progres-

Address for reprint requests: Dr J. Lotfi, Dariush Kabir Medical School, Amirabad Avenue, Teheran, Iran.

Accepted 16 February 1978 sive probable multiple sclerosis, according to the criteria of Allison and Millar (1954) modified by McDonald and Halliday (1977), were studied (Table 1). The different presenting clinical signs and symptoms are shown in Table 2 . The average age of the patients was 35 years, with a range of $22-60$ years.

HLA TYPING

Lymphocytes from peripheral blood were typed using a modified National Institutes of Health (NIH) lymphocytotoxicity test (Van Rood, 1976).

Table 1 Subjects studied

\begin{tabular}{lcrcr}
\hline Category & $\begin{array}{l}\text { Total } \\
\text { number }\end{array}$ & Male & Female \\
\hline Clinically definite multiple sclerosis & 35 & 19 & 16 \\
Progressive probable multiple sclerosis & 8 & 5 & 3 \\
Healthy control subjects & 100 & 51 & 49 \\
\hline
\end{tabular}

Table 2 Presenting symptoms and signs in multiple sclerosis patients (alone or in combinations)

\begin{tabular}{lclc}
\hline Symptoms & $\%$ & Signs & $\%$ \\
\hline Motor weakness & 54 & Paresis of one or & \\
Ataxia & 48 & more limbs & 74 \\
Paraesthesia & 45 & Ataxia & 66 \\
Visual disturbances & 34 & Sensory loss & 43 \\
Urinary symptoms & 34 & Optic atrophy or & \\
Diplopia & 28 & diminished visual & \\
Vertigo & 23 & acuity & 34 \\
Dysarthria & 20 & Nystagmus & 32 \\
Bell's palsy & 8 & Dysarthria & 17 \\
Impotence & 6 & Psychiatric disturbances & 14 \\
Trigeminal neuralgia & 3 & Ophthalmoplegia & 11 \\
\end{tabular}


Nine antigens of the $A$ and 15 antigens of the $B$ locus of the HLA system were defined. Antisera used for typing the patients' cells and those of 100 control subjects were well-defined antisera from Eurotransplant, NIH, and local sources.

\section{Results}

As shown in Table 3 there was a significant increase in the frequency of HLA A3 and A11 in patients with multiple sclerosis compared with controls, with a simultaneous decrease in HLA A10. Table 4 shows the distribution of the B locus antigens. An increased frequency of antigen B7 was observed; in this locus the decrease was distributed more evenly among the other antigens.

Table 3 Distribution of $A$ locus antigens in multiple sclerosis patients and control subjects

\begin{tabular}{|c|c|c|c|c|c|}
\hline \multirow{2}{*}{$\begin{array}{l}\text { HLA } \\
\text { specificity }\end{array}$} & \multicolumn{2}{|c|}{$\begin{array}{l}\text { Multiple sclerosis } \\
\text { patients } \\
(n=35)\end{array}$} & \multicolumn{2}{|c|}{$\begin{array}{l}\text { Control subjects } \\
(n=100)\end{array}$} & \multirow[b]{2}{*}{$x^{2}$} \\
\hline & Number & $\%$ & Number & $\%$ & \\
\hline $\begin{array}{l}\text { A1 } \\
\text { A2 } \\
\text { A3 } \\
\text { A9* } \\
\text { A10* } \\
\text { A11 } \\
\text { A28 } \\
\text { A29 } \\
\text { AW19 }\end{array}$ & $\begin{array}{r}9 \\
10 \\
15 \\
10 \\
2 \\
7 \\
1 \\
0 \\
4\end{array}$ & $\begin{array}{c}25.7 \\
28.5 \\
42.5 \\
28.5 \\
5.7 \\
20 \\
2.8 \\
0 \\
11.4\end{array}$ & $\begin{array}{r}22 \\
28 \\
18 \\
37 \\
16 \\
3 \\
6 \\
1 \\
11\end{array}$ & $\begin{array}{r}22 \\
28 \\
18 \\
37 \\
16 \\
3 \\
6 \\
1 \\
11\end{array}$ & $\begin{array}{l}\text { NS } \\
\text { NS } \\
8.67 \\
\text { NS } \\
\text { NS } \\
10.92 \\
\text { NS } \\
\text { NS } \\
\text { NS }\end{array}$ \\
\hline
\end{tabular}

*A23 and A24 were included in A9; A25 and A26 were included in A10.

$P<0.001$.

Table 4 Distribution of $B$ locus antigens in multiple sclerosis patients and control subjects

\begin{tabular}{|c|c|c|c|c|c|}
\hline \multirow{2}{*}{$\begin{array}{l}\text { HLA } \\
\text { specificity }\end{array}$} & \multicolumn{2}{|c|}{$\begin{array}{l}\text { Multiple sclerosis } \\
\text { patients } \\
(n=35)\end{array}$} & \multicolumn{2}{|c|}{$\begin{array}{l}\text { Control subjects } \\
(n=100)\end{array}$} & \multirow[b]{2}{*}{$x^{2}$} \\
\hline & Number & $\%$ & Number & $\%$ & \\
\hline $\begin{array}{l}\text { B5 } \\
\text { B7 } \\
\text { B8 } \\
\text { B12 } \\
\text { B13 } \\
\text { B14 } \\
\text { B15 } \\
\text { BW16 } \\
\text { BW17 } \\
\text { B18 } \\
\text { BW21 } \\
\text { BW22 } \\
\text { B27 } \\
\text { BW35 } \\
\text { BW40 }\end{array}$ & $\begin{array}{r}12 \\
9 \\
4 \\
4 \\
2 \\
3 \\
1 \\
1 \\
1 \\
5 \\
0 \\
4 \\
1 \\
8 \\
1\end{array}$ & $\begin{array}{l}34 \\
25 \\
11.4 \\
11.4 \\
5.7 \\
8.5 \\
2.8 \\
2.8 \\
2.8 \\
14.2 \\
0 \\
11.4 \\
2.8 \\
22.8 \\
2.8\end{array}$ & $\begin{array}{r}39 \\
8 \\
7 \\
10 \\
9 \\
5 \\
2 \\
6 \\
12 \\
9 \\
3 \\
6 \\
5 \\
15 \\
4\end{array}$ & $\begin{array}{r}39 \\
8 \\
7 \\
10 \\
9 \\
5 \\
2 \\
6 \\
12 \\
9 \\
3 \\
6 \\
5 \\
15 \\
4\end{array}$ & $\begin{array}{l}\text { NS } \\
7.39 \\
\text { NS } \\
\text { NS } \\
\text { NS } \\
\text { NS } \\
\text { NS } \\
\text { NS } \\
\text { NS } \\
\text { NS } \\
\text { NS } \\
\text { NS } \\
\text { NS } \\
\text { NS } \\
\text { NS }\end{array}$ \\
\hline
\end{tabular}

$P<0.005$.
HLA A3 was also increased in cases of probable multiple sclerosis $(37.5 \%$ versus $18 \%$ in controls), but because of the low number of patients it was very difficult to assess precisely the data from this subgroup.

The important point to emphasise is the increased frequency of both A3 and B7 antigens in multiple sclerosis patients $(14 \%$ versus $2 \%$ in controls, Table 5). This suggests a possible haplotype association, but requires further family studies for gene:ical confirmation.

Table 5 Distribution of $A 3$ and $B 7$ antigens in multiple sclero is patients and control :ubjects

\begin{tabular}{lllll}
\hline & $\begin{array}{l}\text { Multiple sclerosis } \\
\text { patients } \\
(n=35)\end{array}$ & $\begin{array}{l}\text { Control } \\
\text { subjects } \\
(n=100)\end{array}$ & $\chi^{2}$ & $R R$ \\
\hline A3 & $42.8 \%$ & $18 \%$ & 8.67 & 3.6 \\
B7 & $25 \%$ & $8 \%$ & 7.39 & 3.7 \\
A3 and B7 & $14 \%$ & $2 \%$ & 8.20 & 5.6 \\
\hline
\end{tabular}

$\mathbf{R} \mathbf{R}=$ Relative risk.

\section{Discussion}

Iran is thought to be situated in a "low risk" zone for multiple sclerosis. In spite of contradictory reports from this part of the world, there is a general acceptance of the idea that a proportion of multiple sclerosis patients show higher than normal frequencies of HLA A3 and B7.

This study was retrospective, using standardised criteria for multiple sclerosis to ascertain cases among whom the genetically antecedent distribution of HLA types might be determined by comparison with healthy controls. Our aim was to find out what proportion, if any, of a multiple sclerosis population may show a predisposition associated with the histocompatibility complex.

Using $\chi^{2}$ test for differences between the two samples and differences from their common (estimated) pool, we have shown that the probabilities of such HLA A and B distributions occurring together are low $(\mathrm{P}=<0.001$ HLA $A$, $<0.008$ HLA B) but the chances that both samples conform to a common underlying histocompatibility pool are relatively high $(P=<0.06$ HLA $A$, $<0.165$ HLA B).

The association found with A3 and B7 is real, but not exclusive-that is, the risk for multiple sclerosis attributable to a histocompatibility association is partial or not fully determined.

The data show that it is worth pursuing these questions because a real association has been detected with the D locus, and the B lymphocyte antigens (Compston et al., 1976). The importance 
of DRW antigens studies in a different population is shown by Kurdi et al. (1977) but, because of the inaccessibility of DRW typing sera, this aspect of the investigation remains to be pursued. That another gene linked to the HLA gene region is more closely associated with multiple sclerosis has been proved by Jersild et al. (1973a, b). They were able to show a much higher association with DW2 which is controlled by genes assumed to be closely linked to immune response genes. The hypothesis of Jersild et al. of sequential intervention of a series of genes progressively more closely linked to another gene responsible for susceptibility to multiple sclerosis was proposed in another way by Terasaki and Mickey (1976). Their hypothesis is that a multiple sclerosis susceptibility gene exists in genetic linkage with the HLA complex. These theories are in agreement with our findings. Our data show that although geographical differences may be very important in multiple sclerosis, genetic predisposition is a major point to consider among other factors. The increased association of A3, B7 haplotype found by several workers in multiple sclerosis emphasises the importance of HLA association with disease (Terasaki and Mickey, 1975). This was also shown by us previously in rheumatoid arthritis with A9, B5 haplotype (Nikbin et al., 1977). An increase of both A3 and B7 in our multiple sclerosis patients can be taken as further evidence in favour of the hypothesis that the gene responsible for susceptibility to the disease could be in the same region and inherited with the corresponding antigens.

In a separate study on the same group of patients (Massoud et al., 1977), we have shown a defect of cell-mediated immunity in multiple sclerosis patients which may correlate well with the above hypothesis, and indicate a broader association of a group of antigens rather than a single antigen.

\section{References}

Allison, R. S., and Millar, J. H. D. (1954). Prevalence and familial evidence of disseminated sclerosis. Ulster Medical Journal, 23, Supplement 2, 11-92.

Bertrams, J., and Kuwert, E. (1976). Association of histocompatibility haplotype HLA-A3-B7 with multiple sclerosis. Journal of Immunology, 117, 1906-1912.

Bertrams, J., Kuwert, E., and Liedtke, V. (1972). HLA antigens in multiple sclerosis. Tissue Antigens, 2, 405-408.
Brautbar, C., Milton, A., and Kahana, E. (1976). HLA antigens in multiple sclerosis. US-Japan Conference on Multiple Sclerosis. Neurology (Minneapolis), 26, 50-53.

Compston, D. A. S., Batchelor, J. R., and McDonald, W. I. (1976). B lymphocyte alloantigens associated with multiple sclerosis. Lancet, 2, 1261-1265.

Jersild, C., Svejgaard, A., and Ammitzboll, F. (1973a). HLA antigens and disease. 1. Multiple sclerosis. Tissue Antigens, 3, 243-250.

Jersild, C., Hansen, G. S., Thomsen, M., Svejgaard, A., and Dupont, B. (1973b). Histocompatibility determinants in multiple sclerosis with special reference to the clinical course. Lancet, 2, 12211224.

Kurdi, A., Addallat, A., Ayesh, I., Maayta, A., McDonald, W. I., Compston, D. A. S., and Batchelor J. R. (1977). Different B lymphocyte alloantigens associated with multiple sclerosis in Arabs and north Europeans. Lancet, 1, 1123-1125.

Kurtzke, J. F. (1977). Geography in multiple sclerosis. Journal of Neurology, 215, 1-26.

Leibewitz, U., and Alter, M. (1973). Multiple Sclerosis: Clues to Its Cause. North-Holland Publishing Company: Amsterdam.

McDonald, I., and Halliday, A. M. (1977). Diagnosis and classification of multiple sclerosis. British Medical Bulletin, 33(1), 4-9.

Massoud, A., Lotfi, J., Derakhshan, I., Emadi, H., and Ala, F. (1977). Study of cell mediated immunity in MS. Presented at 11th world Congress of Neurology, 11-16 September, Amsterdam. Excerpta Medica Congress Proceedings, 427, 264.

Nikbin, B., Nikain, A., Nourbakhsh, S., Ala, F., and White, A. J. (1975). HLA antigens in Iran: histocompatibility testing-75. In Histocompatibility Testing-75, 239-245. Edited by F. Kissmeyer-Nielsen. Munksgaard: Copenhagen.

Nikbin, B., Davatchi, F., and Ala, F. (1977). HLA 9, 5 haplotype in rheumatoid arthritis. Journal of Rheumatology, 4, Supplement 3, 111-112.

Saito, S., Naito, S., Kawanami, S., and Kuroiwa, Y. (1976). HLA studies on multiple sclerosis in Japan. US Japan Conference on Multiple Sclerosis. Journal of Neurology, 26, 49.

Terasaki, P. I., and Mickey, M. R. (1975). HLA haplotype of 32 diseases. Transplantation Review,. 22,. 105-119.

Terasaki, P. I., and Mickey, M. R. (1976). A single mutation hypothesis for multiple sclerosis based on the HLA system. US Japan Conference on Multiple Sclerosis. Neurology (Minneapolis), 26, 56-58.

Van Rood, J. J. (1976). Microlymphotoxicity methods. NIAID Manual of Tissue Typing Techniques. USDHEW Publications No. (NIH 76-545). 